UDC 336.5

JEL Classification: H5, H6

DOI: 10.15587/2706-5448.2021.235630

Article type «Reports on Research Projects»

\title{
Olena Shaporenko \\ BUDGET EXPENDITURE MANAGEMENT IN CONDITIONS OF DECENTRALIZATION ON THE EXAMPLE OF UKRAINE
}

The object of this research is budget expenditures. The limited financial resources are typical for most countries of the world, therefore, it is important to find and improve the ways of forming and implementing the budgetary policy of the state at every stage of the budgetary process. The budget of any country reflects important economic and social aspects of the life of society as a whole and each person individually. Of course, the budget is a powerful regulator of the main economic processes. One of the most problematic areas is ineffective and inefficient use of budget expenditures. Therefore, this study is aimed at developing practical recommendations for optimizing the process of managing budget expenditures in the context of decentralization to ensure sustainable socio-economic development of the state. To achieve this aim, the author used the problems of managing budget expenditures on the example of Ukraine in the context of the introduction of decentralization processes in the country.

The research used the methods of scientific abstraction, systems approach, grouping and classification. To determine the integrated indicator of the efficiency of budget expenditures management at the level of a budgetary institution, society, region, state, a statistical method was used that reflects the correlations of the constituent indicators. To optimize the process of managing budget expenditures, which is considered as a cycle of public policy, two main approaches are proposed. First, a change in the concept of budget expenditures management a transition from the consumption budget to the development budget, which will allow achieving sustainable economic development in the long term. Secondly, it is proposed to introduce an assessment of the effectiveness of budget expenditure management by calculating an integrated indicator, consisting of all components that reflect the effectiveness of the budgetary policy being implemented.

Thanks to the proposed methodology, it is possible to timely adjust the policy for managing budget expenditures in the event of an unsatisfactory value of the integrated indicator of the effectiveness of managing budget expenditures. This provides the advantage that such an adjustment will have a positive effect, since it will be carried out both at the level of a budgetary institution, society, region, and the state as a whole.

Keywords: development expenditures, consumption expenditures, integrated indicator of the efficiency of budget expenditures management.

Shaporenko, O. (2021). Budget expenditure management in conditions of decentralization on the example of Ukraine. Technology Audit and Production Reserves, 3 (4 (59)), 41-45. doi: http://doi.org/10.15587/2706-5448.2021.235630

\section{Introduction}

A well-balanced and planned budget policy should contribute to the sustainable and effective socio-economic development of the state, the main task here is to constantly improve the efficiency of the use of budget funds, the transition from maintaining institutions to providing high-quality services to the population.

All over the world, the problem of the most efficient use of the limited financial resources of the state is sharply raised. This issue is especially relevant in the face of the challenges of our time (economic crises, political confrontations, military conflicts, pandemics). Therefore, economists, scientists, specialists of each country are constantly looking for ways to rationalize the use of budgetary funds.
On the example of Ukraine, this paper highlights the ineffective use of budget funds and substantiates the need to improve the budget expenditure management policy. Measures are proposed that, according to the author, will increase the efficiency of the use of budgetary funds and help to timely respond to negative steps in budgetary policy at the level of an institution, society, region, state.

The imperfection of the budget expenditure management system in Ukraine is evidenced by: an increase in the cost of servicing the public debt (at the beginning of 2010, the total public debt was $34.7 \%$ of GDP and the cost of servicing it was $3.2 \%$ of the total expenditures of the consolidated budget, and by the end of 2020 year $-60.8 \%$ of GDP and $7.6 \%$ of expenditures, according to [1, 2]). A negative trend is the failure to fulfill the strategic goals 
and objectives declared in the main program documents of the state.

One of the important indicators of an imperfect budgetary policy is the impoverishment of the population of Ukraine (the population with an average per capita equivalent total income per month below the actual subsistence minimum in 2014 amounted to $16.7 \%$ of the total population, and in $2020-23.1 \%$ [3]).

Ukraine ranked forty-ninth among 74 developing countries, according to the index of inclusiveness of economic development, assesses the degree of prevalence of positive effects of economic growth on all segments of the population [4].

The issue of efficiency in managing budget expenditures is especially relevant in the context of decentralization in Ukraine, which began at the end of 2014. On June 12, 2020, the Cabinet of Ministers of Ukraine adopted 24 orders to determine the administrative centers and approve the territories of the regions' communities. As a result, 1439 territorial communities were created in the country (excluding territorial communities in the uncontrolled territory within the Donetsk and Luhansk regions), 10,977 territorial communities were united in them, the number of inhabitants of which totals 38.1 million [5]. In the context of ensuring financial decentralization of local authorities, there is a need to optimize budget expenditures.

Analysis of the formation of indicators of the expenditure side of the budget indicates the need to improve approaches to the distribution and use of the limited resource of the state. Therefore, the feasibility of conducting research on the management of budget expenditures, namely, their distribution, the formation and implementation of budget programs, the introduction of an assessment of the effectiveness of budget expenditures management is undoubtedly relevant and has practical and scientific interest.

The object of research is the budget expenditures of Ukraine. The aim of research is to develop practical recommendations for optimizing the process of managing budget expenditures in the context of decentralization to ensure sustainable socio-economic development of Ukraine.

\section{Methods of research}

At all times, many scientists have been solving the problem of optimizing the use of budgetary funds.

Among the significant studies of scientists in the field of public finance [6-8], the problems of rationalizing the use of a limited state resource were studied. Leading scientists carried out a scientific search for ways to achieve a balance between the revenues and expenditures of the budget $[9,10]$. New options for optimizing budget expenditures in modern realities and conditions of economic development are proposed [11-13].

In the studies [14-16], the level and features of the decentralization of the financial system were studied, and the financial viability of the united territorial communities was assessed.

To achieve the set goal of the study, general scientific and special methods and approaches were used. Methods of scientific abstraction, systems approach, grouping and classification are used to reveal practical aspects. And also the definition of factors influencing the decision-making process in managing budget expenditures and criteria for assessing the effectiveness of budget expenditures management, developing proposals and recommendations for optimizing the process of managing budget expenditures in Ukraine. To determine the integrated indicator of the efficiency of budget expenditures management at the level of a budgetary institution, society, region, state, a statistical method was used that reflects the correlations of the constituent indicators.

\section{Research results and discussion}

Despite the processes of decentralization in Ukraine, there is a high level of centralization of budgetary resources. In the structure of revenues (excluding interbudgetary transfers), the share of the state budget is about $80 \%$ in the structure of expenditures (excluding interbudgetary transfers) - up to $60 \%$ [2]. Therefore, considerable attention is paid to the study of the expenditure side of the state budget. In Ukraine, the orientation of budget expenditures on consumption is characteristic (development expenditures are: up to $10 \%$ for the state budget and up to $20 \%$ for local budgets); low level of public investment. In particular, Table 1 shows the dynamics of state budget expenditures on science and economic activity.

Analysis of the structure and dynamics of expenditures indicates that expenditures in these areas are catastrophically low. Developed countries pay more attention to the development of science, and the share of spending on its financing is on average about $3 \%$ of GDP. Indeed, in the modern world, science and innovation play an increasing role in the development of the state and society, meeting the needs and improving the quality of life of people.

Share of state budget expenditures on economic and scientific activities in 2010-2021 on the example of Ukraine*

\begin{tabular}{|c|c|c|c|c|c|c|c|c|c|c|c|c|c|}
\hline Function & СFC & 2010 & 2011 & 2012 & 2013 & 2014 & 2015 & 2016 & 2017 & 2018 & 2019 & 2020 & 2021 (plan) \\
\hline \multicolumn{14}{|c|}{ Economic activity: } \\
\hline Expenses, USD billion & \multirow{3}{*}{$\begin{array}{c}\text { 0400, } \\
\text { incl. } 0480\end{array}$} & 4.5 & 5.6 & 6.2 & 5.2 & 2.9 & 1.7 & 1.2 & 1.8 & 2.3 & 2.8 & 6.3 & 3.5 \\
\hline Share in the SBU total expenses, \% & & 11.9 & 13.4 & 12.5 & 10.2 & 8.0 & 6.4 & 4.6 & 5.6 & 6.5 & 6.7 & 13.1 & 7.3 \\
\hline Share in GDP, \% & & 3.3 & 3.4 & 3.5 & 2.8 & 2.2 & 1.9 & 1.3 & 1.6 & 1.8 & 1.8 & 4.0 & 2.2 \\
\hline \multicolumn{14}{|c|}{ Scientific activity (fundamental applied research and development): } \\
\hline Expenses, USD billion & \multirow{3}{*}{$\begin{array}{l}\text { 0150, 0250, 0370, 0480, } \\
\text { 0530, 0630, 0750, 0840, } \\
\text { 0980, 1080 }\end{array}$} & 0.6 & 0.67 & 0.81 & 0.75 & 0.45 & 0.24 & 0.21 & 0.26 & 0.32 & 0.34 & 0.35 & 0.44 \\
\hline Share in the SBU total expenses, \% & & 1.6 & 1.6 & 1.6 & 1.5 & 1.2 & 0.9 & 0.8 & 0.8 & 0.9 & 0.8 & 0.7 & 0.9 \\
\hline Share in GDP, \% & & 0.4 & 0.4 & 0.5 & 0.4 & 0.3 & 0.3 & 0.2 & 0.2 & 0.2 & 0.2 & 0.2 & 0.3 \\
\hline
\end{tabular}

Note: ${ }^{*}$ - developed on the basis of data [2,3]; CFC - code of functional classification of expenses; 5BU - 5tate Budget of Ukraine 
In managing budget expenditures in Ukraine, it is necessary to completely change the concept of this process. Focus on investment and innovative development is the basis for the country's successful development; the transition from the consumption budget to the development budget is the key to economic growth.

To gradually reduce the public debt, and, accordingly, the cost of servicing the public debt, increase the cost of science and economic activity, let's propose to carry out such unpopular temporary measures (for a period of 5 years) under unchanged conditions for filling the revenue side of the budget:

- reduction of expenses of the general fund of the state budget for all budget programs (expenses for the next budget period should be left at the level of cash expenses of the previous year, in subsequent years to increase expenses by $10 \%$ per year). Under the current cost management policy, the estimated annual cost growth averages $15 \%$;

- direction of $10 \%$ of own revenues of budgetary institutions to pay off debt (with an annual growth of an average of $15 \%$ of own revenues under the code 250100); - reduction of other expenditures of the special fund of the state budget (annually expenditures grow by an average of $15 \%$, it is proposed to ensure an increase of $5 \%$ per year);
- reduction of expenses on subsidies to the population by $15 \%$ annually;

- reduction of the cost of servicing debt, provided that $5 \%$ of the total debt is repaid annually and there are no other debt obligations.

In approximately 5 years, an additional 1.0 USD billion can be allocated to pay off debt and invest in the economy. In particular, it is proposed to approve spending on science in the amount of $3 \%$ of GDP; expenditures on economic activity and capital expenditures should be increased annually by $40 \%$, and the total public debt should be reduced to $33.9 \%$ of GDP. Due to the gradual creation of jobs, an increase in the income of the population, a change in the approach to the payment of subsidies, the costs of subsidies will decrease. Mandatory long-term measures, simultaneously with the reorientation of expenditures, are necessary measures to create conditions by the state for increasing economic activity in society and tough measures to overcome corruption.

It is imperative that we consider it necessary to introduce an assessment of the effectiveness of budget expenditures management according to a certain list of indicators, to form a report on such an assessment with the obligatory requirement to revise the policy in managing expenditures in the event of its low efficiency. Table 2 identifies indicators (quantitative measures) of the effectiveness of budget expenditures management.

Table 2

Indicative list of indicators for assessing the effectiveness of budget expenditure management*

\begin{tabular}{|c|c|c|c|}
\hline Budgetary institution level & Community level & Regional level & At the state level \\
\hline $\begin{array}{l}\text { Budget execution for each budget } \\
\text { program }\end{array}$ & $\begin{array}{l}\text { Community budget execution for each } \\
\text { budget program }\end{array}$ & $\begin{array}{l}\text { Execution of the budget of the } \\
\text { region (region) }\end{array}$ & Budget execution \\
\hline $\begin{array}{l}\text { The level of achievement of indica- } \\
\text { tors of the main result (effect) for } \\
\text { each budget program }\end{array}$ & $\begin{array}{l}\text { Share of transfers in the community } \\
\text { budget }\end{array}$ & $\begin{array}{l}\text { Index of physical volume of gross } \\
\text { regional product (in prices of the } \\
\text { previous year, percent) }\end{array}$ & $\begin{array}{l}\text { Approved medium term budget } \\
\text { declaration }\end{array}$ \\
\hline $\begin{array}{l}\text { The level of achievement of cost } \\
\text { savings for each budget program }\end{array}$ & $\begin{array}{l}\text { Local budget forecast for the medium } \\
\text { term is accepted }\end{array}$ & Gross regional product per person & $\begin{array}{l}\text { State budget of Ukraine was ap- } \\
\text { proved on time }\end{array}$ \\
\hline $\begin{array}{l}\text { Level of achievement of medium-term } \\
\text { and strategic goals of the institution }\end{array}$ & Community budget approved on time & $\begin{array}{l}\text { Number of jobs created in the } \\
\text { region }\end{array}$ & $\begin{array}{l}\text { The number of changes made to the } \\
\text { State Budget of Ukraine }\end{array}$ \\
\hline $\begin{array}{l}\text { The proportion of not achieved } \\
\text { performance indicators (less than } \\
60 \% \text { of implementation) and justifi- } \\
\text { cation of the reasons }\end{array}$ & $\begin{array}{l}\text { The number of changes made to the } \\
\text { community budget }\end{array}$ & $\begin{array}{l}\text { Number of regional investment } \\
\text { projects introduced }\end{array}$ & State budget deficit \\
\hline $\begin{array}{l}\text { Number of violations of budget } \\
\text { legislation revealed }\end{array}$ & $\begin{array}{l}\text { Share of capital expenditures in the } \\
\text { community budget }\end{array}$ & $\begin{array}{l}\text { Regional human development } \\
\text { index }\end{array}$ & $\begin{array}{l}\text { State budget expenditures as a GDP } \\
\text { percentage }\end{array}$ \\
\hline $\begin{array}{l}\text { Number of sanctions applied for } \\
\text { violation of budget legislation }\end{array}$ & Community рег capita income & $\begin{array}{l}\text { Level of achievement of strategic } \\
\text { goals (from regional strategic } \\
\text { documents) }\end{array}$ & $\begin{array}{l}\text { Total government debt as a GDP } \\
\text { percentage }\end{array}$ \\
\hline $\begin{array}{l}\text { The strategic plan of the institution } \\
\text { was approved }\end{array}$ & $\begin{array}{l}\text { The number of investment projects that } \\
\text { are introduced in the community }\end{array}$ & - & GDP рег capita \\
\hline Share of capital expenditures & $\begin{array}{l}\text { Number of newly created infrastructure } \\
\text { facilities }\end{array}$ & - & $\begin{array}{l}\text { Share of transfers to local budgets in } \\
\text { the structure of expenditures }\end{array}$ \\
\hline- & $\begin{array}{l}\text { Number of public meetings held on } \\
\text { community budget use }\end{array}$ & - & Share of capital expenditures \\
\hline- & $\begin{array}{l}\text { The number of the community's } \\
\text { proposals taken into account in the } \\
\text { community budget }\end{array}$ & - & $\begin{array}{l}\text { Spending on science as a GDP } \\
\text { percentage }\end{array}$ \\
\hline- & $\begin{array}{l}\text { The level of satisfaction of the commu- } \\
\text { nity with the quality of administrative } \\
\text { services (survey) }\end{array}$ & - & $\begin{array}{l}\text { Level of achievement of strategic } \\
\text { goals (by industry, in-state strategic } \\
\text { documents) }\end{array}$ \\
\hline- & $\begin{array}{l}\text { Number of sanctions applied for viola- } \\
\text { tion of budget legislation }\end{array}$ & - & $\begin{array}{l}\text { Ukraine's place in international rank- } \\
\text { ings (index of economic freedom, index } \\
\text { of prosperity, index of competitiveness } \\
\text { of ability, budget transparency) }\end{array}$ \\
\hline
\end{tabular}

Note: ${ }^{*}$ - compiled by the author 
The proposed list is not exhaustive and can be supplemented. It can be unified, but it will be clarified as society develops and innovations are introduced in legislation. In order to assess the effectiveness of the budget expenditure management process for each indicator, it is necessary to develop a scale with assignment of points. With this planned value of the indicator, the upper scale (the highest score) corresponds.

At the same time, let's propose to calculate an integrated indicator of the effectiveness of budget expenditure management for the corresponding period at the level of an institution, society, region, state. To do this, each indicator must be assigned a specific weight (using the method of expert assessments) and calculate such an indicator using the formula:

$$
I=\sum_{i=1}^{N} k_{i} \cdot \frac{i_{a}}{i_{p l}}
$$

where $I$ - integrated indicator of the efficiency of budget expenditure management; $k_{i}$ - the weighting coefficient of the $i$-th indicator (criterion) $\sum k_{i}=1 ; N-$ number of indicators (criteria); $I_{a}$ - actual value of the indicator - the score obtained according to the scale; $I_{p l}$ - planned value of the indicator - the maximum score of the scale for the indicator.

A general assessment of the effectiveness of the budget expenditure management process can then be carried out according to Table 3 . The revision of the budget expenditure management policy should be carried out with the assessment «no» or «slightly effective».

To test the proposed methodology, an integrated indicator of the efficiency of state budget expenditure management was calculated using the example of Ukraine based on the results of 2019 (Table 4)

The implementation of the state budget in 2019 is $95.2 \%$ of the planned assignments. Expenditures amounted to $20.5 \%$ of GDP. The share of capital investments in 2019 is $7.1 \%$ of the total cash expenditures. The share of spending on science was $0.22 \%$ of GDP. The share of transfers in the total volume of state budget expenditures in 2019 is $24.2 \%$.
Numerical and qualitative value of the integrated indicator for assessing the effectiveness of budget expenditure management*

\begin{tabular}{|l|l|l|l|}
\hline \multicolumn{1}{|c|}{ Numerical value } & \multicolumn{1}{|c|}{ Qualitative assessments } & $\begin{array}{c}\text { Performance assessment } \\
\text { (or effective cost management) }\end{array}$ & Assessment result \\
\hline Less than 0.5 & «Unsatisfactory execution» & «Not» & Cancellation of policy \\
\hline $\begin{array}{l}\text { Greater/equal to 0.5, } \\
\text { but less than 0.75 }\end{array}$ & «Satisfactory execution» & «Moderately effective» & Revision of policy \\
\hline $\begin{array}{l}\text { More/equal to 0.75, } \\
\text { but less than 1 }\end{array}$ & «Good execution» & «Largely effective» & $\begin{array}{l}\text { Adjustments to some } \\
\text { activities }\end{array}$ \\
\hline Exactly 1 & «Full execution» & «Yes» & Policy unchanged \\
\hline
\end{tabular}

Note: ${ }^{*}$ - compiled by the author

Table 4

Assessment of the effectiveness of state budget expenditure management on the example of Ukraine based on the results of 2019

\begin{tabular}{|c|c|c|c|c|}
\hline Indicators & Scale & Score & $\begin{array}{c}\text { Indicator } \\
\text { weight }\end{array}$ & Index \\
\hline $\begin{array}{l}\text { Execution of the } \\
\text { state budget }\end{array}$ & $\begin{array}{l}\text { Up to } 50 \%-0 \text { paints } \\
\text { From } 50.1 \% \text { to } 70 \%-1 \text { point } \\
\text { From } 70.1 \% \text { to } 80 \%-2 \text { points } \\
\text { From } 80.1 \% \text { to } 90 \%-3 \text { points } \\
\text { From } 90.1 \% \text { to } 100 \%-4 \text { points }\end{array}$ & 4 & 0.025 & $4 / 4 \cdot 0.025=0.025$ \\
\hline $\begin{array}{l}\text { Approved medium } \\
\text { term budget dec- } \\
\text { laration }\end{array}$ & $\begin{array}{l}\text { Yes }-4 \text { points } \\
\text { Yes, but in violation of the terms }-2 \text { points } \\
\text { No }-0 \text { points }\end{array}$ & 0 & 0.025 & $0 / 4 \cdot 0.025=0$ \\
\hline $\begin{array}{l}\text { The state budget of } \\
\text { Ukraine was ap- } \\
\text { proved on time }\end{array}$ & $\begin{array}{l}\text { Yes }-4 \text { points } \\
\text { No }-0 \text { points }\end{array}$ & 4 & 0.025 & $4 / 4 \cdot 0.025=0.025$ \\
\hline $\begin{array}{l}\text { The number of } \\
\text { changes made to } \\
\text { the State Budget of } \\
\text { Ukraine }\end{array}$ & $\begin{array}{l}\text { From } 0 \text { to } 5-4 \text { points } \\
\text { From } 6 \text { to } 10-2 \text { points } \\
\text { More than } 10-0 \text { points }\end{array}$ & 4 & 0.025 & $4 / 4 \cdot 0.025=0.025$ \\
\hline $\begin{array}{l}\text { State budget deficit } \\
\text { as a GDP percent- } \\
\text { age }\end{array}$ & $\begin{array}{l}\text { Up to } 1.5 \% \text { of GDP }-4 \text { points } \\
\text { From } 1.6 \% \text { to } 3 \%-2 \text { points } \\
\text { More than } 3 \% \text { of GDP - } 0 \text { points }\end{array}$ & 2 & 0.1 & $2 / 4.0 .1=0.05$ \\
\hline $\begin{array}{l}\text { State budget ex- } \\
\text { penditures (exclud- } \\
\text { ing interbudgetary } \\
\text { transfers) as a } \\
\text { percentage of GDP }\end{array}$ & $\begin{array}{l}\text { Up to } 20 \% \text { of GDP }-4 \text { points } \\
\text { From } 20.1 \% \text { to } 30 \%-2 \text { points } \\
\text { More than } 30.1 \% \text { of GDP }-0 \text { points }\end{array}$ & 2 & 0.05 & $2 / 4 \cdot 0.05=0.025$ \\
\hline $\begin{array}{l}\text { Total government } \\
\text { debt as a GDP per- } \\
\text { centage }\end{array}$ & $\begin{array}{l}\text { Up to } 35 \% \text { of GDP }-4 \text { points } \\
\text { From } 35.1 \% \text { to } 50 \%-3 \text { points } \\
\text { From } 50.1 \% \text { to } 59.9 \%-2 \text { points } \\
\text { More than } 60 \% \text { of GDP }-0 \text { points }\end{array}$ & 2 & 0.1 & $2 / 4 \cdot 0.1=0.05$ \\
\hline GDP per capita & $\begin{array}{l}\text { More than 35,000 USD - } 4 \text { points } \\
\text { From 20,000 USD to 34,999 USD - } 3 \text { points } \\
\text { From 10,000 USD to 19,999 USD - } 2 \text { points } \\
\text { From 3,000 USD to 9,999 USD - } 1 \text { point } \\
\text { 2,999 USD - 0 points }\end{array}$ & 1 & 0.1 & $1 / 4 \cdot 0.1=0.025$ \\
\hline $\begin{array}{l}\text { Share of transfers } \\
\text { to local budgets } \\
\text { in the structure of } \\
\text { state budget expen- } \\
\text { ditures }\end{array}$ & $\begin{array}{l}\text { Up to } 10 \%-4 \text { points } \\
\text { From } 10.1 \% \text { to } 20 \%-3 \text { points } \\
\text { From } 20.1 \% \text { to } 30 \%-2 \text { points } \\
\text { More than } 30.1 \%-0 \text { points }\end{array}$ & 2 & 0.1 & $2 / 4 \cdot 0.1=0.05$ \\
\hline $\begin{array}{l}\text { Share of capital } \\
\text { expenditures in } \\
\text { total expenditures }\end{array}$ & $\begin{array}{l}\text { From } 0 \% \text { to } 10 \%-0 \text { points } \\
\text { From } 10.1 \% \text { to } 20 \%-2 \text { points } \\
\text { From } 20.1 \% \text { to } 30 \%-3 \text { points } \\
\text { More than } 30.1 \%-4 \text { points }\end{array}$ & 0 & 0.2 & $0 / 4 \cdot 0.2=0$ \\
\hline $\begin{array}{l}\text { Spending on } \\
\text { science as a GDP } \\
\text { percentage }\end{array}$ & $\begin{array}{l}\text { Up to } 0.5 \% \text { of GDP }-0 \text { points } \\
\text { From } 0.51 \% \text { to } 1 \%-1 \text { point } \\
\text { From } 1.1 \% \text { to } 2 \%-2 \text { points } \\
\text { From } 2.1 \% \text { to } 3 \%-3 \text { points } \\
\text { More than } 3.1 \% \text { of GDP }-4 \text { points }\end{array}$ & 0 & 0.2 & $0 / 4 \cdot 0.2=0$ \\
\hline $\begin{array}{l}\text { Ukraine's place in } \\
\text { the international } \\
\text { ranking Prosperity } \\
\text { Index }\end{array}$ & $\begin{array}{l}\text { From } 1 \text { to } 20 \text { places }-4 \text { points } \\
\text { From } 21 \text { to } 50 \text { places }-3 \text { points } \\
\text { From } 51 \text { to } 80 \text { places }-2 \text { points } \\
\text { From } 81 \text { to } 120 \text { places }-1 \text { point } \\
\text { After } 121 \text { st place }-0 \text { points } \\
\end{array}$ & 1 & 0.05 & $1 / 4 \cdot 0.05=0.0125$ \\
\hline \multicolumn{4}{|c|}{ Integrated indicator of the effectiveness of cost management (I) } & 0.2875 \\
\hline
\end{tabular}

Note: ${ }^{*}$ - the calculations were compiled by the author on the basis of $[1-3,17-19]$ 
The state budget deficit amounted to $1.96 \%$ of GDP, and the total public debt - $50.3 \%$. GDP per capita was 3,659.8 USD. In the international ranking of the Prosperity Index in 2019, Ukraine took 96th place out of 167 countries.

The budget declaration for 2019-2021 was not approved. The Law of Ukraine «On the State Budget of Ukraine» was adopted on November 23, 2018. During the year, changes were made to it 4 times.

Thus, the integrated indicator of the efficiency of state budget expenditure management in 2019 is $I=0.2875$, the value of which indicates unsatisfactory performance and the need to reverse the policy course.

Taking this into account, the government, when drawing up the draft state budget for the next budget periods, should have taken a package of measures to change the course of budgetary policy to improve its effectiveness.

In this methodology for assessing effectiveness, it is important to determine a stable list of indicators, the specific weight of each of them and the scale for determining points directly, therefore, in the future, this methodology requires further research. Of course, at the institution level, such an assessment of the effectiveness of budget expenditure management will be more indicative, since it will cover all aspects of the activities of a budgetary institution and identify indicators where the influence of other factors is insignificant.

\section{Conclusions}

The necessity of changing the concept of budget expenditures management is substantiated - the transition from the consumption budget to the development budget, the focus on innovative and investment development of the state and the corresponding direction of funds for certain priorities.

It is proposed to introduce an assessment of the efficiency of budget expenditures management by calculating an integrated indicator for timely adjustment of the expenditure management policy. The main goal of the above described technique is not a simple counting of numbers, but a guide to action. If the integrated indicator indicates the need to revise the policy, then it is imperative to develop and implement measures to adjust it. Therefore, it is advisable to legislatively regulate the issue of assessing the effectiveness of budget expenditure management at the state level.

An important aspect is that the assessment of the effectiveness of budget expenditure management at the level of the community, region, state should be carried out by an independent organization from among experts and experienced economists, which will provide analytical support for the Ministry of Finance of Ukraine, macroeconomic forecasts of economic and social development. The function of assessing the effectiveness of budget expenditure management should be assigned to the same institution.

The measures outlined in the work will change the approach to the vision of the concept of «budget expenditures management» and consider the definition not just as a process, a set of methods and tools. It is proposed to consider the management of budget expenditures as a state policy in the field of organizing effective, rational and efficient distribution and use of budgetary resources in order to achieve the strategic goals of the socio-economic development of the state. State policy is defined as a system of actions, regulatory measures relating to certain areas of activity of executive authorities.

The formation and implementation of state policy has a cycle of functioning: definition, regulation by regulatory legal acts, implementation plan, monitoring, assessment and revision. After all, public policy making is an ongoing process with feedback mechanisms. Verification and assessment are essential for the functioning of this system. That is why let's emphasize the importance of assessing the effectiveness of budget expenditure management as a state policy. This is especially important now, when changes in society are very dynamic and require the search for new, effective and efficient ways to solve social problems.

Possible areas for further research could be:

- improvement of the proposed methodology for assessing the effectiveness of budget expenditure management in terms of developing unified indicators for assessing efficiency at the level of an institution, society, region, state; - development of a mechanism for assigning weighting factors for each of the indicators and a scoring matrix (scale) for each of the indicators.

\section{References}

1. Derzhavnyi borh Ukrainy. Minfin. Available at: https://index. minfin.com.ua/ua/finance/debtgov/

2. Derzhavna kaznacheiska sluzhba Ukrainy. Available at: https://www. treasury.govua/ua/file-storage/vikonannya-derzhavnogo-byudzhetu

3. Derzhavna sluzhba statystyky. Available at: http://www.ukrstat. gov.ua/

4. The Inclusive Development Index 2018. (2018). Available at: https://www.weforum.org/reports/the-inclusive-developmentindex-2018

5. Detsentralizatsiia. Available at: https://decentralization.gov.ua/ newgromada

6. Buchanan, J. M., Musgrave, R. A. (1999). Public Finance and Public Choice: Two Contrasting Visions of the State. The MIT Press, 282

7. Keyne, J. M. (2016). The General Theory of Employment, Interest, and Money. Stellar Classics, 168.

8. Friedman, M. (2003). Capitalism and Freedom. University of Chicago Press, 230.

9. Vasyutinska, L. (2019). Improving of budget expenditures management effectiveness: problems and pragmatics. SocioEconomic Research Bulletin, 1 (69), 140-148. doi: http://doi.org/ 10.33987/vsed.1(69).2019.140-148

10. Yefymenko, T. I. (2017). Fiscal space and stabilization of public finance. Finansy Ukrainy, 9, 7-28. Available at: http://nbuv. gov.ua/UJRN/Fu_2017_9_3

11. Kudriashov, V. P. (2018). Management of budget operations according to fiscal rules. Finansy Ukrainy, 12, 31-51. Available at: http://nbuv.gov.ua/UJRN/Fu_2018_12_4

12. Lukianenko, I. H. (2004). Systemne modeliuvannia pokaznyki biudzhetnoi systemy Ukrainy: pryntsypy ta instrumenty. Kyiv: Vyd. dim «Kyievo-Mohylianska akademiia», 542.

13. Lunina, I. (2019). Conceptual basics of public finance sustainability. Finansi Ukraini, 11, 97-109. doi: http://doi.org/10.33763/ finukr2019.11.097

14. Pavliuk, K. V. (2006). Biudzhet i biudzhetnyi protses v umovakh tranzytyonoi ekonomiky Ukrainy. Kyiv: NDFI, 584

15. Buriachenko, A., Levchenko, K. (2019). Behavioral economy and decentralization of the budget system. Finansi Ukraini, 9, 27-42. doi: http://doi.org/10.33763/finukr2019.09.027

16. Ljutyj, I., Spasiv, N. (2019). Assessment of the financial capacity of united territorial communities. Finansi Ukraini, 7, 92-112 doi: http://doi.org/10.33763/finukr2019.07.092

17. Richnyi zvit pro vykonannia biudzhetu stanom na 01.01.2020 roku. Available at: https://www.treasury.gov.ua/ua/file-storage/richnijzvit-pro-vikonannya-derzhavnogo-byudzhetu-ukrayini-za-2019-rik

18. Finansozyi portal Minfin. Available at: http://index.minfin.com.ua/ budget/

19. The Legatum Prosperity Index. Available at: https://www.prosperity.com/

Olena Shaporenko, Postgraduate Student, Department of Budget Policy and Budget System Development, State Educational and Scientific Institution «Academy of Financial Management», Kyiv, Ukraine, e-mail: shaporenko2708@gmail.com, ORCID: https://orcid.org/ 0000-0001-5252-7056 